\title{
Studi Deskripsi Jenis-Jenis Pantun Rejang Dalam Masyarakat Kabupaten Lebong
}

\author{
Eko Anderman \\ Universitas Bengkulu \\ Ekoanderman22@gmail.com \\ Resnani \\ Universitas Bengkulu \\ Resnani12@gmail.com \\ Daimun Hambali \\ Universitas Bengkulu \\ Daimunhambali@gmail.com
}

\begin{abstract}
This study aims to describe the types of rhymes in the Rejang language found in the Lebong community of Bengkulu Province. The approach and type of research used is a qualitative survey. The research locations were Tik Teleu Village, Pelabai, and Kota Baru Santan, Pelabai District, Lebong Regency, Bengkulu Province. Subjects were used as informants. In this study, the traditional leader of Lebong Regency, from Tik Teleu Village and Pelabai Village. Data collection The techniques used in this study were interviews with informants and documentation. Data analysis techniques were data selection, data presentation, conclusion drawing, and data validity test, namely by lengthening observations, increasing persistence, triangulating (triangulating sources) and holding member checks. The results of the study were collected sixty rhymes in the rejang language pantun found in three villages and documentation. The Rejang language is nineteen rhymes from Tik Teleu Village, eighteen rhymes from Kota Baru Santan Village and sixteen rhymes from Pelabai Village and added from the documentation (Book of ireak Ca'o tun Jang) as many as seven rhymes, so there are sixty rhymes. In accordance with the types of rhymes obtained, namely: eleven advice rhymes, five love rhymes, two spirit poems, six traditional rhymes, six religious rhymes, one humorous rhyme, nine figurative rhymes, twelve love rhymes, five proverb rhymes and three puzzles. puzzle. As for the types of Rejang language rhymes that can be used as learning material for local content in elementary schools, there are nine rhymes consisting of eight advice rhymes, two spirit rhymes, five religious rhymes and three puzzle rhymes and one humorous rhyme.

Key words : The Rejang language rhymes, Study description of rhymes, The Lebong community
\end{abstract}

\section{Pendahuluan}

Pembelajaran bahasa Indonesia di SD mencangkup beberapa materi yang terdiri dari kebahasaan, keterampilan, dan sastra, salah satu bentuk pembelajaran sastra adalah pantun. Seperti yang tertera dalam Kemendikbud (2014: 66)menjelaskan dalam kurikulum 2013, pantun menjadi bagian dari pembelajaran yang diajarkan karena dimaksudkan untuk membantu peserta didik memperoleh wawasan pengetahuan yang lebih luas agar mampu bertindak efektif dalam 
menyelesaikan permasalahan dikehidupan nyata. Selanjutnya menurut Suwarni (2018: 13) menyatakan bahwa pantun merupakan salah satu karya sastra yang cocok diberikan untuk pembelajaran siswa SD karena sudah sangat memasyarakat dalam kehidupan. Pentingnya pembelajaran pantun sudah tertera pada permendikbud no 37 tahun 2018yaitu terdapat di kelas VI kompetensi dasar 3.6 Menggali isi dan amanat.

Pantun yang disajikan secara lisan dan tulisan dengan tujuan untuk kesenangan pantun merupakan jenis puisi lama yang masih ada hingga saat ini, pantun biasa digunakan masyarakat sebagai alat berkomunikasi. Misalnya pantun sering digunakan sebagai alat komunikasi dalam acara adat pernikahan, yang maksud di dalam pantunnya terkandung nilai-nilai pendidikan dan moral. Sebagaimana dijelaskan Pangesti (2014: 7) bahwa pantun merupakan salah satu jenis puisi lama yang sangat luas dikenal dalam bahasa-bahasa Nusantara. Misalnya dalam bahasa Minangkabau pantun dikenal sebagai penuntun, bahasa sunda misalnya pantun dikenal sebagai paparikan dan dalam bahasa jawa pantun dikenal sebagai parikan.

Setiap daerah memiliki karya sastra pantun yang berbeda-beda sesuai dengan bahasa dan ciri khas daerahnya masing-masing. Namun seiring kemajuan zaman dan teknologi membuat keberadaan pantun sudah mulai tergusur oleh jenis-jenis karya seni yang lain. Sebagaimana diungkapkan oleh Mafrukhi (2007: 92) pantun merupakan tradisi lisan yang masih bertahan di beberapa daerah di Indonesia dan masih menempati posisi penting dalam masyarakat. Namun seiring berkembangnya zaman yang dipengaruhi oleh perubahan dalam era globalisasi kebiasaan berpantun dalam masyarakat mulai hilang. Saat ini, keberadaan pantun terkesan dipinggirkan dan sudah sangat jarang orang ataupun para sastrawan menulis pantun. Terpinggirkanya pantun disebabkan karena kurangnya minat masyarakat dalam melestarikan pantun terutama generasi muda yang terbawa arus globalisasi, seperti lebih memilih budaya luar dari pada budayanya sendiri. Salah satu contohnya dapat kita lihat di dalam acara pernikahan yang lebih memilih menggunakan organ tunggal dibandinggan menggunakan kebudayaanya sendiri seperti berbalas pantun.

Pergeseran pantun juga dirasakan oleh masyarakat yang berada di Kabupaten Lebong. Padahal di Kabupaten Lebong pantun merupakan salah satu aset daerah yang seharusnya dijaga dan dilestarikan oleh seluruh kalangan masyarakat, karena pantun bahasa Rejang mengandung nilai beragama, moral dan budaya. Sebagaimana yang diungkapkan Wiguna (2017: 115) menunjukkan bahwa pantun memiliki nilai pendidikan yang tinggi dan di dalam pantun sering kali ditemukan nasehat-nasehat dalam menjalani kehidupan, nasehat tersebut bisa dijadikan pedoman tuntunan hidup serta nilai pendidikan dalam beragama, moral, maupun budaya.

Pantun bahasa Rejang merupakan sastra daerah yang menjadi cagar budaya dan ilmu pengetahuan bagi masyarakat di daerah dan dapat menjadi budaya nasional. Jadi sudah seharusnya sebagai generasi penerus bangsa mengetahui, mempelajari dan menghidupkan kembali budaya yang tinggi nilainya, sehingga karya sastra pantun dapat terjaga kelestariannya. Namun kenyataannya yang ada di lapangan menunjukkan bahwa tidak semua masyarakat Rejang mengenal sastra yang ada di daerahnya sendiri.

Membuat sastra daerah berupa pantun bahasa Rejang lama-kelamaan akan dilupakan oleh masyarakat dan tidak diketahui oleh generasi penerus. Hal ini sejalan dengan hasil penelitian Zamhari (2013) yang menunjukkan bahwa kalangan orang tua yang masih memahami dan menguasai dinamika kebudayaan suku Rejang sekarang sudah semakin berkurang. Mereka pada umumnya tidak meninggalkan bukti tertulis tentang seluk kebudayaan Rejang. Jika kondisi ini terus berlangsung, 
lama kelamaan kebudayaan suku Rejang tidak akan dikenal oleh generasi penerus termasuk pantun bahasa Rejang.

Berdasarkan wawancara yang dilakukan pada tanggal 29 Juni 2020 dengan ketua adat di Kecamatan Pelabai yaitu bapak Samidi, beliau mengatakan bahwa pada zaman dahulu pantun digunakan sebagai alat komunikasi di kalangan masyarakat, baik itu berupa nasehat maupun sebagai hiburan semata. Selain itu pantun juga menjadi hal yang wajib ada pada kegiatan pernikahan. Namun pada saat ini pantun bahasa Rejang sudah jarang digunakan dalam berkomunikasi ataupun acara adat pernikahan, karena masyarakat lebih banyak tertarik menggunakan budaya luar dibandingkan budaya lokal. Hal ini sejalan dengan pendapat Adrian \& Resmini (2018: 14) yang menjelaskan bahwa globalisasi menimbulkan berbagai masalah dalam bidang kebudayaan, misalnya hilangnya budaya asli suatu daerah atau suatu negara, terjadinya erosi nilai nilai budaya, menurunnya rasa nasionalisme dan patriotisme, hilangnya sifat kekeluargaan dan gotong royong, kehilangan kepercayaan diri, gaya hidup yang tidak sesuai dengan adat.

Hal tersebut juga disebabkan kurang adanya keinginan masyarakat dan generasi muda untuk mempelajari pantun sehingga sangat sulit untuk menemukan orang yang pandai menulis dan berpantun. Memudarnya pemahaman terhadap pantun bahasa Rejang juga dikarenakan kurang dikenalnya materi pantun di sekolah-sekolah. Hal ini disebabkan keterbatasan kemampuan guru dalam mengajarkan pantun. Sejalan dengan pendapat Apriansah (2018: 43) bahwa pantun kurang diajarkan bahkan tidak diajarkan di sekolah-sekolah karena guru kurang mampu untuk mengajarkan pantun dengan baik, sehingga siswa tidak tertarik dan merasa bosan dengan pembelajaran pantun.

Pada proses pembelajaran di sekolah, guru lebih memilih menghindari materi pantun karena kurangnya kemampuan memilih strategi yang baik sehingga guru hanya memberikan contoh pantun tanpa mengajarkan anak tentang konsep pantun itu sendiri. Sejalan dengan pendapat Suastika (2014) yang menyatakan bahwa di dalam proses belajar-mengajar, guru harus memiliki strategi, agar siswa dapat belajar secara efektif dan efisien, mengena pada tujuan yang diharapkan.

Untuk melestarikan pantun bahasa Rejang, maka peneliti akan mendeskripsikan, mengumpulkan dan mengidentifikasi kumpulan pantun bahasa Rejang yang ada di masyarakat berdasarkan jenis-jenis pantun. Hal ini untuk menggali pengetahuan tentang pantun bahasa Rejang dan etnis Rejang. Penelitian yang dilakukan terhadap pantun bahasa Rejang sangat penting karena pantun memiliki manfaat serta nilai-nilai kehidupan yang ada di masyarakat. Banyaknya pantun yang ada di masyarakat Lebong dapat dibedakan berdasarkan jenis-jenis pantun yang ada, sehingga masyarakat dapat mengetahui dan memahami jenisjenis pantun yang ada. Hal ini sejalan dengan hasil penelitian yang dilakukan oleh Fandi (2012: 286) yang memperoleh hasil " Pantun minangkabau di pasa lamo terdiri dari 4 pantun dagang, 7 pantun berkenalan, 3 pantun berkasih sayang, 8 pantun adat, dan 10 pantun agama".

Sehubungan dengan beberapa masalah di atas, pantun bahasa Rejang Kabupaten Lebong tidak ada dibukukan secara khusus dan sangat jarang ditemukan penggunaannya baik di acara adat pernikahan maupun sebagai sarana berkomunikasi. Maka dari itu, peneliti ingin mengumpulkan dengan cara mendeskripsikan pantun-pantun bahasa Rejang sesuai dengan jenis-jenis pantun, agar dapat mengetahui jenis-jenis pantun yang terdapat di masyarakat Kabupaten Lebong. Berdasarkan masalah tersebut maka peneliti tertarik melakukan penelitian tentang "Studi Deskripsi Jenis-jenis Pantun Bahasa Rejang dalam Masyarakat Kabupaten Lebong Provinsi Bengkulu". Penelitia ini bertujuan untuk untuk 
mendeskripsikan jenis-jenis pantun bahasa Rejang yang terdapat dalam masyarakat Lebong Provinsi Bengkulu.

\section{Metode}

Jenis Penelitian menggunakan jenis penelitian kualitatif dengan metode survey. Dalam penelitian ini data yang dikaji dan dideskripsikan sehingga diperoleh gambaran tentang pantun bahasa Rejang sesuai dengan jenis-jenis pantun. Menurut Moleong (2015: 6) penelitian kualitatif adalah penelitian yang bermaksud untuk memahami fenomena tentang apa yang dialami oleh subjek penelitian, misalnya perilaku, persepsi, motivasi, tindakan dan lain sebagainya.

Subjek dalam penelitian ini, diistilahkan dengan informan karena dalam pantun-pantun yang tersedia peneliti adalah sebagai rekan langsung dari informan. Informan tersebut adalah masyarakat yang memahami pantun bahasa Rejang. Subjek penelitiannya yaitu masyarakat suku Rejang yang berada di Kabupaten Lebong Provinsi Bengkulu.

Penelitian ini difokuskan untuk mencari data tentang Jenis-jenis Pantun Bahasa Rejang dalam Masyarakat Kabupaten Lebong Provinsi Bengkulu. Penelitian ini dilaksanakan di Desa Tik Teleu, Pelabai, dan Kota Baru Santan, Kecamatan Pelabai Kabupaten Lebong Provinsi Bengkulu..

Menurut Sugiyono (2018: 276) menyatakan bahwa teknik pengumpulan data merupakan langkah yang paling strategis dalam penelitian, karena dalam tujuan penelitian adalah mendapatkan data. Adapun teknik pengumpulan data dalam penelitian ini adalah wawancara dan dokumentasi.

Instruman yang digunakan untuk melengkapi data dalam penelitian ini yaitu pedoman wawancara dan pedoman dokumentasi. Wawancara dilakukan kepada informan sebagai sumber data untuk mencari data tentang pantun bahasa Rejang yang ada di masyarakat Rejang Kabupaten Lebong. Wawancara dilakukan kepada pakar yang ahli dalam berpantun. Hal ini bertujuan untuk mendapatkan data yang lengkap, akurat dan mendalam. Sedangkan dokumentasi digunakan untuk mengumpulkan data yang dilakukan dengan cara menghimpun atau mengumpulkan dokumen-dokumen yang berisi catatan peristiwa yang sudah berlalu, biasa berbentuk tulisan, gambar atau karya-karya dari seseorang. Dokumentasi dalam penelitian ini bertujuan untuk mencari catatan-catatan, gambar dan jurnal tentang pantun yang ada di masyarakat.

\section{Hasil Penelitian}

Pantun yang terkumpulah dari beberapa pantun di buku Ireak Ca’o Kutai Jang dan informan yang berasal dari masyarakat suku Rejang Provinsi Bengkulu, Kabupaten Lebong, Kecamatan Pelabai, pada Desa Pelabai, Kota Baru Santan, dan Tik Teleu. Dari beberapa desa tersebut, peneliti mendapatkan hasil wawancara berupa pantun Bahasa Rejang dariinforman yaitu ketua adat Kabupaten Lebong bapak Samidi dari Desa Tik Teleu dan Rusli Desa Pelabai. Dari hasil wawancara dan jumlah pantun yang terkumpul dari informan sebanyak 53 pantun Bahasa Rejang yaitu 19 pantun dari Desa Tik Teleu, 18 pantun dari Desa Kota Baru Santan dan 16 pantun dari Desa Pelabai dan ditambah dari dokumentasi (Buku ireak Ca'o tun Jang) sebanyak 7 pantun, jadi ada 60 buah pantun.Berikut ini disimpulkan hasil pantun yang diperoleh :

1. Kumpulan pantun yang diperoleh dari hasil wawancara

a. Kumpulan pantun yang ada di masyarakat suku Rejang oleh bapak Samidi, Desa Tik Teleu 
Berdasarkan hasil wawancara dengan bapak Samidi diperoleh data bahwa Perkembangan pantun bahasa Rejang dalam masyarakat Lebong saat ini sangat memprihatikan. Penggunaan pantun dalam kehidupan sehari-hari sudah tidak ada lagi. Pantun dan budaya seperti bedeker, mecok, dan berdendang harus dilestarikan karena itu adalah kebudayaan yang memiliki nilai kehidupan bermasyarakat. Saat sekarang ini, generasi muda tidak tertarik lagi dengan hal-hal tersebut karena menurut mereka sudah kuno, sehingga mereka lebih menyukai budaya modern dari luar. Muda mudi dulu menggunakan pantun sebagai sarana berkenalan dengan lawan jenis,sehingga pantun dikuasi oleh muda mudi dan juga masyarakat. Selain itu zaman sekarangjarangditemukkan lagi guru yang mengajarkan pantun karena ahli pantun biasanya lebih di dominasi oleh orang tua. Karena dasarnya pantun diturunkan secara turun temurun, tetapi sekarang hal tersebut sudah tidak lagi diterapkan karena kurangnya minat generasi muda untuk mempelajari pantun.

Menurut bapak Samidi Pada dasarnya pantun digunakan sebagai alat komunikasi di dalam masyarakat untuk menyampaikan keinginan dan pendapat. Dalam pantun bahasa Rejang tidak terdapat perbedaan dengan pantun yang lainnya, jenis pantunnya dibedakan tegantung kondisi penggunaan pantun tersebut. Ada pun pantun bahasa Rejang yang terdapat di Desa Tik Teleu Kabupaten Lebong ada 19 pantu.

b. Kumpulan pantun yang ada di masyarakat suku Rejang oleh bapak Rusli, Desa Pelabai

Berdasarkan hasil wawancara dengan bapak Rusli diperoleh data bahwa dalam masyarakat suku Rejang pantun sudah tidak pernah digunakan lagi. Masyarakat lebih senang dengan budaya asing seperti musik Modern dan musik organ tunggal yang sering digunakan dalam acara pernikahan. Pantun bahasa Rejang dahulu memang diturunkan seacara turun temurun oleh orang tua kepada anaknya, akan tetapi sekarang generasi muda tidak memiliki keinginan untuk mempelajari pantun. Saat sekarang ini pantun bahasa Rejang sudah jarang digunakan lagi oleh masyarakat, baik dalam berkomunikasi, perkenalan muda mudi dan dalam kegiatan adat. Pada zaman dahulu pantun digunakan sebagai alat untuk menasehati anak atau pun sebagai sindiran kepada orang lain. Sejatinya tidak ada perbedaan antara pantun bahasa Rejang dengan pantun lain, perbedaannya hanya terdapat pada bahasanya saja. Fungsi pantun bahasa Rejang adalah sebagai alat komunikasi yang digunakan masyarakat baik unuk memperkenalkan diri, menasehati, menyindir dan dalam acara adat. Ada pun pantun bahasa Rejang yang terdapat di Desa Pelabai Kabupaten Lebong ada enam belas pantun.

c. Kumpulan pantun yang ada di masyarakat suku Rejang oleh Ibu Nurida, Desa Kota Baru Santan

Berdasarkan hasil wawancara dengan Ibu Nurida diperoleh data bahwa perkembangan pantun bahasa Rejang di dalam kehidupan masyarakat Lebong untuk saat ini boleh dibilang tidak ada lagi atau punah. Hal ini diakibatkan masuknya budaya asing dan kurangnya minat generasi muda untuk mempelajari dan melestarikan pantun. Pantun bahasa Rejang dulunya memang diturunkan secara turun temurun oleh orang tua kepada anaknya, namun untuk sekarang sudah tidak lagi diterapkan karena anak sudah tidak tertarik dengan pantun lagi. Pada saat sekarang ini pantun bahasa Rejang sudah sangat jarang digunakan. Pantun hanya dapat dijumpai pada acara adat, itu pun hanya sedikit masyarakat menggunakannya. Pembagian Jenis-jenis pantun bahasa Rejang itu tergantung pada siapa ia menggunakan dan situasi apa ia menggunakan. Pantun yang penuh dengan nilai pendidikan dan kehidupan sangat pening untuk dilestarikan salah satunya ialah denganmeningkatkan rasa penasaran anak terhadap pantun, dengan cara setiap acara pernikahan maupun pembelajaran di sekolah diselingi dengan 
Anderman, E., Resnani, Daimun, H.

berpantun. Ada pun pantun bahasa Rejang yang terdapat di Desa Kota Baru Santan Kabupaten Lebong ada delapan belas pantun.

\section{Kumpulan Pantun Yang Diperoleh Dari Hasil Dokumentasi}

Berdasarkan hasil penelitian yang dilaksanakan di Kabupaten Lebong, ditemukan beberapa pantun yang ada di dalam bukuIreak ca'o Kutai Jang ada tujuh pantun.

\section{Identifikasi Pantun Bahasa Rejang Berdasarkan Jenis-Jenis Pantun}

Dari hasil penelitian tiga Desa yang sudah dilaksanakan, seseuai dengan jenisjenis pantun di buku Ireak Ca'o Kutai Jang dan informan yang berasal dari masyarakat suku Rejang Provinsi Bengkulu, Kabupaten Lebong, Kecamatan Pelabai, pada Desa Pelabai, Kota Baru Santan, dan Tik Teleu.

Berdasarkan Hasil identifikasidisimpulkan bahwa, dari 60 pantun bahasa Rejang, yang disesuaikan dengan jenis-jenis pantun diperoleh terdapat 11 pantun nasehat, 5 pantun kasih sayang, 2 pantun semangat, 6 pantun adat, 6 pantun agama, 1 pantun jenaka, 9 pantun kiasan, 12 pantun percintaan, 5 pantun peribahasa dan 3 pantun teka-teki. Sedangkan untuk jenis-jenis pantun Bahasa Rejang yang bisa dijadikanmateri pembelajaran muatan lokal di SD ada 19 pantun yang terdiri dari 8 pantun nasehat, 2 pantun semangat, 5 pantun agama dan 3 pantun teka-teki dan 1 pantun jenaka.

\section{Pembahasan}

\section{Deskripsi Pantun Bahasa Rejang Sesuai Dengan Jenis - Jenis Pantun}

Perkembangan zaman dan teknologi saat sekarang ini, membuat terjadinya pergeseran terhadap kebiasaan masyarakat terdahulu dengan sekarang, yang membuat pengenalan pantun yang dulunya sering digunakan dalam acara adat pernikahan, komunikasi ketika pergaulan, namun sekarang jarang digunakan lagi dalam komunikasi atau acara adat di tengah masyarakat Lebong. Seperti dalam dalam berkomunikasi ataupun acara adat pernikahan sudah jarang digunakan, karena masyarakat lebih banyak tertarik menggunakan budaya luar dibandingkan budaya lokal. Sehingga generasi muda kurang mengetahui dan memahami tentang pantun bahasa Rejang. Hal ini sejalan dengan penelitian Amar (2016) menjelaskan bahwa disayangkan puisi-puisi rakyat tersebut akhir-akhir ini sudah agak jarang dituturkan, khususnya oleh generasi muda. Hal ini disebabkan oleh kurangnya minat generasi muda daerah tersebut untuk mempelajari dan menggunakannya. Sedangkan dalam Depdiknas (2006:50) dinyatakan bahwa pantun sebagai puisi rakyat merupakan salah satu sastra lisan yang berhubungan dengan tradisi atau adat-istiadat dan budaya suatu daerah yang dapat menunjang serta menambah perkembangan sastra Indonesia.

Dalam penelitian ini peneliti sudah mengelompokkan beberapa jenis serta maknanya pantun yang terdapat di Kabupaten Lebong, dengan harapan pantun bahasa Rejang tetap dilestarikan agar dapat menambah pengetahuan untuk generasi muda tentang pantun. Seperti yang diungkapkan oleh Mihardja (2012: 12) menyatakan bahwa makna pantun ditentukan oleh isi. Dan makna dari pantun sesuai dengan tujuannya, misalnya, pantun bermakna nasehat, makna pengajaran, ungkapan perasaan hati, makna menghibur, makna keagamaan atau religi, makna budaya, makna mengajak untuk berpikir, atau makna lelucon. Sedangkan menurut Santoso (2013: 12-14) setiap pantun yang diciptakan mempunyai fungsi atau kegunaannya sendiri. Diantaranya yaitu pertama fungsi pendidikan sebagai alat untuk menyampaikkan nasehat dan ilmu pengetahuan. Kedua fungsi kasih sayang dan cinta digunakan unruk mengungkapkkan perasaan kasih sayang dan cinta. 
Ketiga fungsi penghargaan atau terima kasih, pantun ini digunakan untuk mengenang budi dan jasa seseorang. Keempat fungsi kecerdasan berbahasa, pantun ini juga diciptakan dengan tujuan mengukur kecerdasan berbahasa. Semakin baik pantun yang diciptakan oleh seseorang.

Pantun bahasa Rejang merupakan salah satu aset daerah yang seharusnya dijaga dan dilestarikan oleh seluruh kalangan masyarakat, karena pantun bahasa Rejang mengandung nilai beragama, moral dan budaya. Dari hasil penelitian terdapat jenis-jenis pantun yang terdapat di Kabupaten Lebong yaitu pantun nasehat, pantun kasih sayang, pantun semangat, pantun adat, pantun agama, pantun jenaka, pantun kiasan, pantun percintaan,teka-teki dan pantun peribahasa.

Deskripsi Pantun Bahasa Rejang Sesuai Dengan Jenis - Jenis pantun adalah sebagai berikut :

\section{a. Pantun Nasehat}

Pantun nasehat di atas merupakan jenis pantun nasehat karena yang isinya mengandung nasehat kepada orang lain dengan tujuan mengajak kearah yang lebih baik. Hal tersebut sesuai dengan pendapat Wahyuni (2014: 155), bahwa pantun nasehat adalah jenis pantun lama yang berisi nasehat dengan tujuan untuk mengajak kebaikan atau mengajak untuk menjadi lebih baik lagi dalam menjalani hidup. Menurut (2013: 13), bahwa pantun nasehat dapat diberikan dari orang tua. Hal ini juga selaras dengan pendapat Ganie (2015: 17), pantun sebagai alat untuk menyampaikan nasihat dan didikan, terutamanya golongan orang tua. Pantun di atas memiliki makna bahwa dalam menuntut ilmu harus bersungguh-sunguh karena ilmu tersebut akan menjadi bekal sampai tua nantinya. Berdasarkan makna dari pantun tersebut dapat disimpulkan bahwa pantun tersebut termasuk ke dalam jenis pantun nasehat.

\section{b. Pantun Kasih Sayang}

Pantun di atas merupakan jenis pantun kasih sayang karena menggambarkan tentang perasaan kasih dan sayang kepada orang lain atau sesamanya, seperti kekasih hati, sahabat, keluarga maupun suami istri. Menurut Wahyuni (2014: 157) mengungkapkan bahwa pantun kasih sayng adalah jenis pantun lama yang menggambarkan tentang perasaan kasih dan sayang kepada keluarga, saudara, suami/istri, kekasih, sahabat dan sesamanya. Selaras dengan pendapat tersebut Santoso (2013: 13) mengatakan bahwa pantun juga digunakan untuk mengungkapkan perasaan kasih sayang dan cinta. Pantun di atas menggambarkan tentang kerinduan seorang anak terhadap orang tuanya yang teramat dalam. Berdasarkan gambaran isi pantun tersebut dapat disimpulkan bahwa pantun di atas termasuk ke dalam jenis pantun kasih sayang.

\section{c. Pantun Semangat}

Pantun di atas merupakan jenis pantun semangat karena pesan di dalam pantun memberikan semangat kepada diri sendiri maupun orang lain yang mendengarnya. Sesuai dengan pendapat Wahyuni (2014: 159) pantun semangat adalah jenis pantun lama yang berisi kata-kata penggugah atau pembangkit semangat. Pantun di atas memberikan pesan agar selalu bersemangat dalam bertani (sawah) agar hasil panen bisa berlimpah. Berdasarkan pesan yang ada pada pantun di atas dapat dikatakan bahwa pantun tersebut digolongkan kedalam jenis pantun semangat.

\section{d. Pantun Adat}

Pantundiatas merupakan jenis pantun adat karena meberikan pesan dan ajaran kepada orang lain agar selalu melestarikan adat yang ada. Hal tersebut 
sejalan dengan pendapat Wahyuni (2014: 161), bahwa pantun adat adalah jenis pantun lama yang berasal dari suatu daerah, serta memiliki ciri khas gaya bahasa yang sangat kental dengan unsur budaya atau adat. Hal ini juga dijelaskan oleh Ganie (2015: 36) bahwa pantun adat berfungsi sebagai nasehat yang berhubungan adat istiadat yang berlaku dan dari hasil identifikasi terdapat dua pantun adat. Pantun di atas memberi pesan ketika ingin menyampaikkan sesuatu keinginan dalam acara seperti lamaran pernikahan, berasan kutai dalam pernikahan, penyambutan tamu penting, jangan lupa membawa sawo/kolak dan permata adat (sirih) sebagai penghormatan. Berdasarkan pesan yang ada dalam pantun di atas dapat digolongkan bahwa pantun tersebut adalah jenis pantun adat.

\section{e. Pantun Agama}

Pantun di atas merupakan jenis pntun agama karena memberikan tata cara dan pengetahuan tentang ajaran agama. Sesuai dengan pendapat Wahyuni (2014: 164) bahwa pantun agama adalah jenis pantun lama yang berisi pengajaran tentang segala hal yang berhubungan dengan agama. Menurut Andriani (2017: 13) pantun agama adalah jenis pantun yang mengandung nasehat sesuai ajaran agama. Berisi tentang apa yang harus dan tidak boleh dikerjakan sehingga mengingat untuk tetap teguh pada agama. Pantun di atas memberikan pesan walaupun kita hebat dan memiliki semuanya (harta dan tahta) jangan pernah lupa dengan allah SWT yang maha pemberi, maka harus menjaga sholat lima sebagai rasa syukur kepada allah dan harus selalu diingat semua yang diberikan sama allah itu bentuknya titipan. Berdasarkan pesan yang ada dalam pantun di atas dapat digolongkan bahwa pantun tersebut adalah jenis pantun agama.

\section{f. Pantun Jenaka}

Pantun di atas termasuk pantun jenaka karena lucu dan orang yang mendengarnya menjadi senang dan terhibur. Menurut Santoso (2013: 13) bahwa pantun jenaka dijadikan sebagai hiburan bagi masyarakat. Hal tersebut sejalan dengan pendapat Wahyuni (2014: 164) bahwa pantun jenaka adalah jenis pantun lama yang ditunjukan untuk menghibur hati orang banyak. Oleh karena itu, pantun di atas digolongkan jenis pantun jenaka karena orang yang mendengarnya akan menjadi terhibur.

\section{g. Pantun Kiasan}

Pantun di atas merupakan jenis pantun kiasan karena mengunakan kata-kata kiasan untuk menambah kesan yang indah dalam pengucapan, menyampaikan maksud dan tujuan, akan tetapi pendengar harus mencari tahu arti atau makna dari pantun yang telah diberikan agar pesan yangdapat diterima dan tidak salah dalam mengartikannya. Seperti yang diungkapkan oleh Wahyuni (2014: 168) bahwa pantun kiasan adalah jenis pantun lama yang menggunakan kata-kata kiasan. Pantun tersebut digolongkan ke dalam jenis pantun kiasan karena dibagian isi pantun menggunaan kata kiasan.

\section{h. Pantun Percintaan}

Pantun di atas merupakan jenis pantun percintaan karena isi pantunya bertujuan untuk mengungkapkan rasa cinta terhadap seseorang. Menurut Wahyuni (2014: 170) bahwa pantun percintaan adalah jenis pantun lama yang isinya menggambarkan tentang perasaan cinta dan segala suka dukanya. Pantun di atas menggambarkan tentang sepasang kekasih yang tida memperdulikan perkataan orang lain dan tetap teguh pada janji yang telah mereka buat. Berdasarkan pesan yang ada dalam pantun di atas dapat digolongkan bahwa pantun tersebut adalah jenis pantun percintaan. 


\section{h. Pantun Peribahasa}

Pantun di atas merupakan jenis pantun peribahasa karena mengungkapkan sesuatu menggunakan perumpamaan atau perbandingan.Seperti yang diungkapkan Wahyuni (2014: 172) bahwa pantun peribahasa adalah jenis pantun lama berisi kalimat-kalimat peribahasa yang di dalamnya terdapat perbandingan, perumpamaan, nasehat, prinsip hidup, atau aturan tingkah laku. Pantun ini berisi kalimat peribahasa untuk mengungkapkan sesuatu nasehat yang memiliki tujuan yang baik. Berdasarkan pesan yang ada dalam pantun di atas dapat digolongkan bahwa pantun tersebut adalah jenis pantun peribahasa.

\section{i. Pantun teka-teki}

Pantundi atas merupakan jenis pantun teka-teki karena pada dua baris terakhirnya berbentuk pertanyaan. Hal tersebut sesuai dengan pendapat Wahyuni (2014: 152) bahwa pantun teka-teki adalah jenis pantun yang berbentuk pertanyaan yang biasa digunakan untuk mendidik dan melatih kemampuan anak dalam berpikir mencari jawaban dari pertanyaan yang terkandung di dalam pantun tersebut. Pantun di atas dapat digolongkan ke dalam jenis pantun teka-teki karena dua baris terakhir berbentuk pertanyaan.

\section{Deskripsi Pantun Bahasa Rejang Sesuai dengan Ciri-ciri Pantun a. Pantun terdiri atas 4 baris dan bersajak $a-b-a-b$}

Pantun adalah salah satu karangan puisi lama yang telah banyak diketahui oleh masyarakat luas. Pantun sendiri dibentuk berdasarkan bait-bait dan dari bait tersebut terdiri atas baris-baris yang menjadi satu membentuk karangan pantun yang kaidah serta bunyi dari pantun sendiri telah diatur. Dalam penelitian ini semua pantun yang berhasil dikumpulkan oleh peneliti terdiri empat baris yang pada akhir kalimat pantun memiliki pola a-b-a-b. Sebagaimana diungkapan Purwandari (2015: 167) pantun adalah puisi yang bercirikan bersajak a-b-a-b, tiap bait 4 baris.

Dari pantun tersebut dapat dilihat bahwa garis kesatu yaitu Putiak awok tun cino, baris ke dua Teglicia neak daet pun jambau, baris ketiga Walau awok gerot ngen kayodan baris ke empat Meak coa tinget semyang lemo waktau. Sedangkan pada pola diakhir kalimatnya terlihat pada barisan pertama bersaja a, barisan kedua bersajak b, barisan ke tiga bersajak a dan barisan ke empat bersajak b.Jadi dapat disimpulkan bahwa pantun tersebut sesuai dengan ciri-ciri pantun yang ada yaitu berjumlah empat baris dan bersaja a-b-a-b. Seperti dalam penelitian Amar (2016) menyatakan bahwa lazimnya pantun terdiri atas empat larik (atau empat baris bila dituliskan), bersajak akhir dengan pola a-b-ab dan a-a-a-a (tidak boleh $a-a-b-b$, atau a-b-ba).

\section{b. Dua baris pertama merupakan sampiran}

Pantun berjumlah empat baris dengan dua baris pertama merupakan sampiran dari pantun tersebut. Sampiran adalah dua baris pertama yang biasanya berkaitan dengan alam dan budaya masyarakat.Dari pantun yang ditemukan dapat dilihat bahwa baris kesatu dan baris kedua merupakan sampiran. Jadi dapat disimpulkkan bahwa pantun tersebut sesuai dengan ciri-ciri pantun yang ada yaitu dua baris pertama merupakan sampiran. Seperti yang di ungkapkan Pradopo (2002:224) bahwa aturan-aturan pantun yang utama ialah (1) tiap baris terdiri atas 4 baris pada umumnya, (2) baris pertama dan kedua merupakan sampiran,baris ketiga dan keempat merupakan isinya, (3)sajak akhirnya berpola ab-ab, (4) tiap baris terdiri atas dua periodus, tiap periodus terdiri atas dua kata pada umumnya.

\section{c. Dua baris kedua merupakan isi}


Pantun berjumlah empat baris dengan dua baris pertama merupakan sampiran dan dua dua baris kedua merupakan isi dari pantun tersebut. Isi pantun merupakan tujuan dari sebuah pantun.Dari pantun yang ditemukan dapat dilihat bahwa baris ketiga dan baris ke empat merupakan isi. Jadi dapat disimpulkan bahwa pantun tersebut sesuai dengan ciri-ciri pantun yang ada yaitu dua baris kedua merupakan isi. Seperti yang di ungkapkan oleh Kuncoro (2013) beberapa ciri-ciri pantun yaitu pertama pantun terdiri dari 2 sampai 4 baris atau lebih. Kedua baris pertama dan bari kedua atau baris awalan sampiran. Ketiga barisan ketiga dan ke empat atau baris akhir merupakan isi/maksud yang hendak disampaikkan.

\section{d. Jumlah kata tiap baris terdiri dari 8-12 suku kata.}

Jumlah baris dari pantun paling sedikit 8 suku kata dan paling banyak 12 kata, seperti yang ditemukan oleh peneliti dilapangan jumlah kata dari pantunnya berkisar 8 sampai 12 kata.Dari pantun yang ditemukan dapat dilihat bahwa barisan pertama memiliki 9 suku kata, baris kedua memiliki 10 suku kata, baris ketiga memiliki 8 suku kata dan barisan ke empat memiliki 8 suku kata. Jadi dapat disimpulkan bahwa pantun tersebut sesuai dengan ciri-ciri pantun yang ada, yaitu jumlah kata tiap baris terdiri dari 8-12 suku kata. Seperti yang diungkapkan Nursisto (2000:11) ada beberapa syarat pantun yaitupertamatiap bait terdiri atas empat baris. Kedua tiap baris terdiri atas 8 sampai 12 suku kata. Ketiga sajaknya berumus abab. Keempat kedua baris pertama merupakan sampiran sedangkan isinya terdapat pada kedua baris terakhir. Dan sejalan dengan menurut Sudaryat (2006:170) mengemukakan bahwa pantun merupakan hasil karya sastra puisi lama yang berupa puisi asli yang bentuknya terdiri atas empat baris sebait dengan rumus sajak a-b-a-b. Setiap baris biasanya terdiri atas 8-12 suku kata. Baris pertama dan kedua berupa sam-piran, sedang baris ketiga dan keempat berupa isi.

\section{Mendeskripsikan Makna Pantun Sesuai dengan Jenis-jenis Pantun}

Pantun memiliki makna yang bermacam-macam sesuai dengan isi dan jenis pantun. Seperti yang ditemukan di lapangan ada beberapa makna pantun yang bisa diambil yaitu berisi makna keagamaan atau religi, makna budaya, bermakna nasehat, makna pengajaran, ungkapan perasaan hati, atau makna menghibur. Seperti yang diungkapkan oleh Utami (2013:16) bahwa pantun memiliki bermacammacam makna, yaitu makna ungkapan atau curahan perasaan, makna nasehat, makna pengajaran, makna hiburan, makna budaya, makna religi, makna bermain tebak-tebakan, dan lain-lain. Dan sejalan dengan pendapat Mihardja (2012:12), makna pantun ditentukan oleh isi. Berdasarkan isinya, pantun memiliki bermacammacam makna sesuai dengan tujuannya. Misalnya, pantun bermakna nasehat, makna pengajaran, ungkapan perasaan hati, makna menghibur, makna keagamaan atau religi, makna budaya, makna mengajak untuk berpikir, atau makna lelucon.

\section{Keterkaitan Pantun Bahasa Rejang Terhadap Pembelajaran Muatan Lokal Di SD}

Berdasarkan hasil identifikasi terdapat beberapa pantun yang bisa dijadikan materi dalam pembelajaran muatan lokal yang ada di Sekolah Dasar (SD) seperti pantun nasehat, pantun semangat, pantun agama, pantun teka-teki dan pantun jenaka.

\section{Simpulan}


Berdasarkan hasil penelitian dan pembahasan tentang identifikasi pantun Bahasa Rejang sesuai dengan jenis-jenis pantun di Kabupaten Lebong, khusus Kecamatan Lebong Atas, Desa Tik Teleu, Kota Baru Santan dan Pelabai dapat disimpulkan bahwa jumlah pantun yang terkumpul dari informan sebanyak 53 pantun Bahasa Rejang yaitu 19 pantun dari Desa Tik Teleu, 18 pantun dari Desa Kota Baru Santan dan 16 pantun dari Desa Pelabai dan ditambah dari dokumentasi (Buku ireak Ca'o tun Jang) sebanyak 7 pantun, jadi ada 60 buah pantun.

Jenis-jenis Pantun Bahasa Rejang dalam Masyarakat Kabupaten Lebong, Kecamatan Lebong Atas yang diambil dari tiga Desa yaitu dari Desa Tik Teleu, Kota Baru Santan, dan Pelabai. Berdasarkan jenis-jenis pantun secara umum ada 10 pantun yaitu pantun nasehat, pantun kasih sayang, pantun semangat, pantun adat, pantun agama, pantun jenaka, pantun kiasan, pantun percintaan, pantun peribahasa dan pantun teka-teki. Berdasarkan hasil identifikasidisimpulkan bahwa, dari 60 pantun bahasa Rejang, yang disesuaikan dengan jenis-jenis pantun diperoleh terdapat 11 pantun nasehat, 5 pantun kasih sayang, 2 pantun semangat, 6 pantun adat, 6 pantun agama, 1 pantun jenaka, 9 pantun kiasan, 12 pantun percintaan, 5 pantun peribahasa dan 3 pantun teka-teki. Sedangkan untuk jenis-jenis pantun Bahasa Rejang yang bisa dijadikanmateri pembelajaran muatan lokal di SD ada 19 pantun yang terdiri dari 8 pantun nasehat, 2 pantun semangat, 5 pantun agama dan 3 pantun teka-teki dan 1 pantun jenaka.

Dari Pantun yang ditemukan memiliki makna yang bermacam-macam sesuai dengan isi dan jenis pantun. Seperti yang ditemukan di lapangan ada beberapa makna pantun yang bisa diambil yaitu berisi makna keagamaan atau religi, makna budaya, bermakna nasehat, makna pengajaran, ungkapan perasaan hati, atau makna menghibur.

\section{Saran}

1. Kurangnya masyarakat yang masih mengetahui pantun bahasa Rejang, khususnya orang tua, sudah banyak yang lupa karena berkurangnya kegiatan yang berhubungan dengan penggunaan pantun. Sebaiknya kegiatan berpantun dikembangkan dalam masyarakat dan didokumentasikan baik itu dalam bentuk buku maupun catatan agar diketahui generasi penerus.

2. Sebaiknya pantun bahasa Rejang dapat dikembangkan dan dijadikan sebagai salah satu materi di dalam pembelajaran muatan lokal di sekolah-sekolah sehingga dapat memberikan pengetahuan dan menumbuhkan minat pada generasi muda untuk mempelajari pantun bahasa Rejang.

3. Bagi peneliti selanjutnya agar dapat lebih luas mengumpulkan pantun bahasa

Rejang lebih banyak lagi sehingga pantun bahasa Rejang dapat dilestarikan.

\section{Referensi}

Adrian, H dan Resmini, W. 2018. Pengaruh Globalisasi Terhadap Nilai-Nilai Budaya pada Rumah Tradisional Masyarakat Sade Lombok Tengah. CIVICUS : Pendidikan-Penelitian-Pengabdian Pendidikan Pancasila dan Kewarganegaraan, 6 (2), 13-22.

Andriani, R. 2017. Pembelajaran Mengidentifikasi Informasi Dari Pantun Yang Berorientasi Pada Pesan Dan Rima Dengan Menggunakan Metode Two Stay Two Stray Pada Siswa Kelas VII SMP Pasundan 4 Bandung Tahun Pelajaran 2016/2017. FKIP Unpas. 
Amar. C. 2016. Korelasi Kemampuan Memahami Ciri Pantun dan Kemampuan Menentukan Jenis Pantun dengan Kemampuan Menulis Pantun Siswa Kelas VIII SMP Negeri I Pagaralam. Jurnal Pembelajaran Bahasa dan Sastra Indonesia. Volume 6, No. 1, Tahun 2016. Guru SMPN I Pagaralam Sumatra Selatan.

Apriansah, D., Muktadir, A., dan Lusa, H. 2018. Studi Identifikasi Jenis-Jenis Pantun dalam Masyarakat Kaur Provinsi Bengkulu. Jurnal PGSD: Jurnal Ilmiah Pendidikan Guru Sekolah Dasar, 11(1), 43-50.

Depdiknas. 2008. Peraturan Mentri Pendidikan Nasional. Jakarta: Direktorat Jenderal Manajemen Pendidikan Dasar dan Menengah.

Ganie, T. N. 2015. Buku Induk Bahasa Indonesia. Araska.Yogyakarta.

Kementerian Pendidikan dan Kebudayaan. 2014. Bahasa Indonesia: Ekspresi Diri dan Akademik. Kementerian Pendidikan dan Kebudayaan. Jakarta.

Kuncoro, F. T. 2013. Peningkatan Kemampuan Menulis Pantun Dengan Pemanfaatan Objek Langsung Pada Siswa Kelas VII B SMP Negeri 6 Banjarnegara Tahun Ajaran 2012-2013. Universitas Muhammadiyah Purwokerto.

Leo Fandi, dkk. 2012. "Struktur dan fungsi Pantun Minangkabau dalam masyarakat pasalamo, pulau Punjung, Dharmasraya". Jurnal Pendidikan Bahasa dan Sastra Indonesia, Vol.1 No september 2012; Seri B 87

Mafrukhi. 2007. Kompenten Berbahasa Indonesia Untuk SMA KeIas XI. ErIangga. Jakarta.

Mihardja, R. 2012. Buku Pintar Bahasa Indonesia. Laskar Aksara. Jakarta.

Moleong, L. J. 2007. Metodologi Penelitian Kualitatif. Remaja Rosdakarya. Badung.

Nursisto. 2000. Ikhtisar Kesustraan Indonesia.Adi cipyta karya nusa. Yogyakarta.

Purwandari, R. 2015. Buku Pintar Bahasa Indonesia. Istana Media. Yogyakarta

Pangesti, M., D. 2014. Buku Pintar Pantun dan Peribahasa. Pustaka Nusantara Indonesia. Jakarta.

Santoso, J. 2013. Pantun Puisi Lama Melayu dan Peribahasa Indonesia. Ariska. Yogyakarta.

Suastika, I. G. P., Artawan, G., \& Sriasih, S. A. P. (2014). Strategi Guru dalam Pembelajaran Menulis Puisi pada Siswa Kelas VII SMP Negeri 1 Banjar. Jurnal Pendidikan Bahasa dan Sastra Indonesia Undiksha, 2(1).

Sudaryat, Ndang. 2006. Ringkasan Baha-sa Indonesia. Ganeca Exact. Bandung Sugiyono. 2018. Statistika untuk penelitian. Alfabeta. Bandung.

Utami. 2013. Pintar Pantun, Puisi, Peribahasa dan Majas. Naafi. Media. Yogyakarta.

Wahyuni, R. 2014. Kitap Lengkap Puisi, Prosa dan Pantun Lama. Saufa. Yogyakarta

Wiguna, M. Z., Yuda, R. K dan Uli. I. 2017. Analisis Nilai-Nilai Pendidikan Dalam Pantun Melayu Sambas. Vol. 6.No.1. IKIP PGRI. Jurnal pendidikan Bahasa Indonesia. Pontianak. 